\title{
COSMID CLONES FROM MICRODISSECTED HUMAN CHROMOSOMAL REGION 15q11-q13
}

\author{
Takaya Tohma, ${ }^{1}$ * Toshiya Tamura,${ }^{3}$ Tohru Ohta,${ }^{2}$ Hidenobu Soejima, ${ }^{2}$ \\ Takeo Kubota, ${ }^{2}$ Yoshihiro Jinno, ${ }^{2}$ Kazuhiro Tsukamoto, ${ }^{2,4}$ \\ Yusuke NaKamura, ${ }^{4}$ Kenji NaritomI, ${ }^{1}$ and Norio NiIKawa ${ }^{2}$ \\ ${ }^{1}$ Department of Pediatrics, University of the Ryukyus School of Medicine, \\ Uehara, Nishihara, Okinawa 903-01, Japan \\ ${ }^{2}$ Department of Human Genetics, Nagasaki University School of Medicine, \\ Sakamoto, Nagasaki 852, Japan \\ ${ }^{3}$ Department of Child Development, Kumamoto University School of Medicine, \\ Honjo, Kumamoto 860, Japan \\ ${ }^{4}$ Department of Biochemistry, Cancer Institute, \\ Kami-Ikebukuro, Toshima-ku, Tokyo 170, Japan
}

Summary A human chromosomal region, 15q11-q13, was microdissected, its DNA was amplified with the primer-linker PCR method, and the PCR products were cloned into a plasmid vector to construct a microclone library. Of 193 microclones analyzed with Southern blot hybridization on hybrid cell panels, $26(13.5 \%)$ were either single-copy (unique) or low-repetitive fragments. By screening of a cosmid library of human genomic DNA using the 26 microclones as probes, 47 positive cosmids were obtained and underwent regional mapping with chromosome fluorescence in situ hybridization (FISH). Sixteen cosmids gave FISH signals at $15 \mathrm{p}$-cen, 5 at 15q11-q13, 6 at 15q22-q26, 3 at other chromosomes, and 17 no signal. These 27 cosmids mapped to chromosome 15 are useful additions to the inventory of DNA markers of this chromosome including the much interested Prader-Willi/Angelman syndrome region.

Key Words cosmid clone, microdissection, FISH, mapping, DNA marker

\section{INTRODUCTION}

A human chromosomal region, 15q11-q13, has a unique cytogenetic property. Since deletions, translocations, and inverted duplications have frequently been

Received May 24, 1993; Revised version accepted July 1, 1993.

*To whom correspondence should be addressed. 
observed at $15 \mathrm{q} 11-\mathrm{q} 13$, the region is considered to be a hot-spot for rearrangements, and this cytogenetic instability may be explained by the presence of highly repetitive sequences, e.g., inverted repeats, in the region (Mattei et al., 1984; Donlon et al., 1986). In addition, chromosome 15 contains highly methylated DNA much more than other acrocentric chromosomes (Okamoto et al., 1981), and the DNA methylation is assumed to play a role in the genomic imprinting process. Actually, abnormalities at $15 q 11-q 13$ are causally associated with Prader-Willi syndrome (PWS) and Angelman syndrome (AS), which are contiguous gene syndromes and good examples of genomic imprinting in the human (Nicholls et al., 1989; Hamabe et al., 1991a, b). A number of DNA markers and at least 6 genes or transcripts have been assigned to this region: the $\mathrm{GABA}_{\triangle}$ receptor $\beta 3$ subunit gene (GABRB3) (Wagstaff et al., 1991), GABA $A_{A}$ receptor $\alpha 5$ subunit gene (GABRA5) (Knoll et al., 1993), DN10 (human homologue of the mouse pink-eyed dilution gene, $P$ ) (Gardner et al., 1992), DN34 (ZNF127) (Waters et al., 1992), the small nuclear ribonucleoprotein polypeptide N gene (SNRPN) (Özcelik et al., 1992), and MN7 (human homologue of a unique gene in the mouse) (Glenn et al., 1993). YAC contigs have also been constructed in this region (Kuwano et al., 1993), but several gaps still remains between the contigs (Donlon, 1992).

Chromosome microdissection is a simple and rapid means to construct a genomic DNA library from a defined chromosomal region. Among region-specific DNA libraries constructed with this method (Lüdecke et al., 1989; Buiting et al., 1990; Hirota et al., 1992; Seki et al., 1993), there has been such a library specific for 15q11-q13 (Buiting et al., 1990), from which several microclones were mapped at a segment involved in deletions among PWS patients (Buiting et al., 1992). However, since a microclone library does not completely cover the DNA at a defined region and the gaps among the YAC contigs at the 15q11-q13 region have not been bridged (Donlon, 1992), more number of cosmid clones are necessary to analyze the genomic structure of the region. Here, we report the results of our microdissection-microcloning at the $15 \mathrm{q} 11-\mathrm{q} 13$ region and the isolation of corresponding cosmid clones.

\section{MATERIALS AND METHODS}

Microdissection and amplification of chromosomal DNA. The procedure of chromosome preparation for microdissection was a modification of the method described previously (Deng et al., 1992; Hirota et al., 1992; Ohta et al., 1993). In short, metaphase spreads were prepared from a human lymphoblastoid cell line. After treatment with a hypotonic solution consisting of $0.2 \% \mathrm{NaCl}$ and $0.2 \% \mathrm{KCl}$, cells were fixed with absolute methanol. A fixed cell suspension $(30 \mu l)$ was mixed with acetic acid $(10 \mu \mathrm{l})$, and then immediately spread on a glass slide. GTG-banding was performed on non-aged chromosomes with $0.025 \%$ trypsin, and then chromosomes were stained with $3 \%$ Giemsa. Procedures of microdissection and enzymatic 
amplification (polymerase chain reaction, PCR) of chromosomal DNA were those described previously (Hirota et al., 1992; Jinno et al., 1992) with a slight modification. A chromosomal region, 15q11-q13, was microdissected with a micromanipulator. One hundred pieces of dissected chromosomal fragments were transferred to a siliconized moist chamber. By lighting the moist chamber which was covered with a cap plugged with wet paper, dewdrops were formed on the collected chromosomal fragments. The dewdrops were covered with paraffin oil saturated with Sau3AI buffer (10 mM Tris- $\mathrm{HCl}$, pH 7.5/7 $\mathrm{mm} \mathrm{MgCl}_{2} / 10 \mathrm{mM} \mathrm{NaCl}$ ), then fused with 2-3 $\mathrm{nl}$ of proteinase $\mathrm{K}$ solution $(0.5 \mathrm{mg} / \mathrm{ml}$ proteinase $\mathrm{K} / 0.1 \% \mathrm{SDS} / 10 \mathrm{~mm}$ Tris$\mathrm{HCl}, \mathrm{pH} 7.5 / 10 \mathrm{~mm} \mathrm{NaCl}$ ) and incubated at $37^{\circ} \mathrm{C}$ for $4 \mathrm{hr}$. DNA extraction, Sau3AI digestion, DNA amplification with the primer-linker PCR method were all the same as described previously (Jinno et al., 1992). Sequences of the linker, MboL1, and the primer, NlaM1, were 5'-GATCCATGTC-3' and 5'-CGGGAATTCTGGCTCTGCGACATG-3', respectively. The DNA was amplified for 30 cycles of PCR with denaturation at $93^{\circ} \mathrm{C}$ for $2 \mathrm{~min}$, annealing at $62^{\circ} \mathrm{C}$ for $2 \mathrm{~min}$ and extension at $72^{\circ} \mathrm{C}$ for $2 \mathrm{~min}$.

Confirmation of localization of PCR product. To confirm the chromosomal derivation of the PCR products, fluorescence in situ hybridization (FISH) was performed on metaphase chromosomes from a karyotypically normal individual as described previously (Deng et al., 1992; Ohta et al., 1993). A 1/100 portion (4 $\mu 1)$ of the first PCR products was PCR-amplified again to be biotin-labeled for 12 cycles in a reaction mixture containing biotin-16-dUTP (100 $\mu$ l) (Boehringer-Mannheim, Germany) and dTTP (100 ul). Human Cot-1 DNA (GIBCO BRL, USA) was used as a competitor. FISH signals were detected with FITC-conjugated avidin (Vector Laboratories Inc., USA), and chromosomes were counterstained with propidium iodide. Photomicroscopy was done under a fluorescence microscope equipped with filter combinations, B-2A and B-2E (Nikon).

Microcloning of PCR products. The first PCR products were ethanol-precipitated and digested with $E c o \mathrm{RI}(50 \mathrm{U})$ at $37^{\circ} \mathrm{C}$ for $4 \mathrm{hr}$. Five microliter of the DNA, dissolved in $100 \mu \mathrm{l}$ of $1 \times \mathrm{TE}$ buffer, was incubated at $16^{\circ} \mathrm{C}$ for $4 \mathrm{hr}$ with $100 \mathrm{ng}$ of dephosphorylated EcoRI-cut pUC19 in a $10 \mu \mathrm{l}$ reaction mixture. The ligation mixture $(5 \mu 1)$ was transformed into competent DH $5 \alpha$ cells.

Southern blot analysis. Inserts of the pUC recombinants (microclones) were digested with EcoRI and isolated by electrophoresis on a $4 \%$ polyacrylamide gel. The insert DNA was used as a probe for Southern blot hybridization of EcoRI- or HindIII-digested genomic DNA from normal human leukocytes, a human-mouse hybrid cell line (GM10500, Coriell Institute, USA) containing a human der(15), $\mathrm{t}(15 ; 17)(\mathrm{q} 22 ; \mathrm{q} 11.2)$, and a hybrid cell line (A9Neo8, kindly provided by Dr. M. Oshimura, Tottori University) containing two human chromosomes 8 . Inserts, which hybridized only to both total human DNA and DNA from GM10500 and contained no highly repetitive sequences, were used as probes for screening of a human cosmid library. 
Screening of a cosmid library. A cosmid library from partial Sau3AI-digests of total human DNA was constructed using a cosmid vector, pWEX15. A mixture of 2 or 3 microclone inserts, having single-copy or low repetitive sequences, was used for screening of the library which was equivalent to 4-fold genomes. DNA on replica nylon filters was prehybridized with $200 \mu \mathrm{g} / \mathrm{ml}$ human placental DNA at $64^{\circ} \mathrm{C}$ for $8 \mathrm{hr}$. Hybridization was performed with ${ }^{32} \mathrm{P}$-labeled microclone inserts at $65^{\circ} \mathrm{C}$ for $10-12 \mathrm{hr}$, the filters were washed twice in $0.1 \times \mathrm{SSC} / 0.1 \% \mathrm{SDS}$ at $65^{\circ} \mathrm{C}$ for $15 \mathrm{~min}$, and positive cosmid clones were isolated. To find overlapping cosmid clones, EcoRI digests were electrophoresed on a $0.8 \%$ agarose gel, transferred on nylon filters and hybridized with each of the microclones. Cosmids independent for their inserts were used as probes for further FISH studies.

Regional mapping of isolated cosmid clones. The isolated cosmids were labeled with biotin-16-dUTP by the use of a nick translation labeling kit (BoehringerMannheim). FISH was performed on R-banded normal metaphase chromosomes as described above.

\section{RESULTS}

\section{Characterization of microclones}

From 100 chromosomal fragments dissected at $15 q 11-q 13$, PCR products of a 150-700 bp size range were obtained. FISH using the PCR products as a probe pool painted the 15 ql1-q13 region, indicating that the PCR products were rich specifically for the DNA at the region. By cloning of the PCR products, a total of 341 pUC-recombinants were obtained. From these microclones, 193 inserts (MCl-MC193) with sizes larger than 150 bp (mean size, approximately $290 \mathrm{bp}$ ) were selected and analyzed. Southern blot analysis revealed that $26(13.5 \%)$ were either single-copy (unique) fragments or low-repetitive sequences, which were all different in size and hybridized to both human genomic DNA and GM10500 DNA but not to A9Neo8 DNA (Fig. 1), 105 (54.4\%) highly repetitive or smear-appearing sequences, and $62(32.1 \%)$ the fragments not hybridized to human or mouse DNA (Table 1).

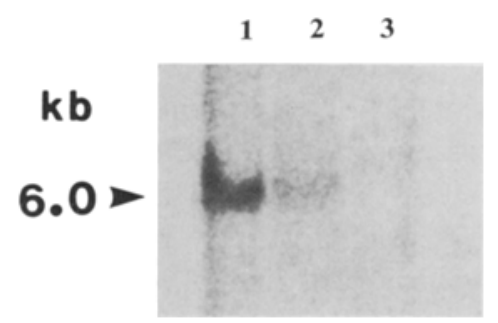

Fig. 1. Hybrid cell panel analysis with a microclone pM15C17, showing a single-copy signal in both total human DNA (1) and DNA from a human mouse hybrid cell-line containing a human der(15) chromosome (2), but no signal in DNA from the other hybrid cell without human chromosome 15 (3). 
Table 1. Results of Southern blot analysis of microclones from 15q11-q13.

\begin{tabular}{lr} 
Signals & Number of microclones \\
\hline Single-copy or low-repetitive & $26(13.5 \%)$ \\
Highly repetitive or smeary & 105 \\
None & 62 \\
Total & 193 \\
\hline
\end{tabular}

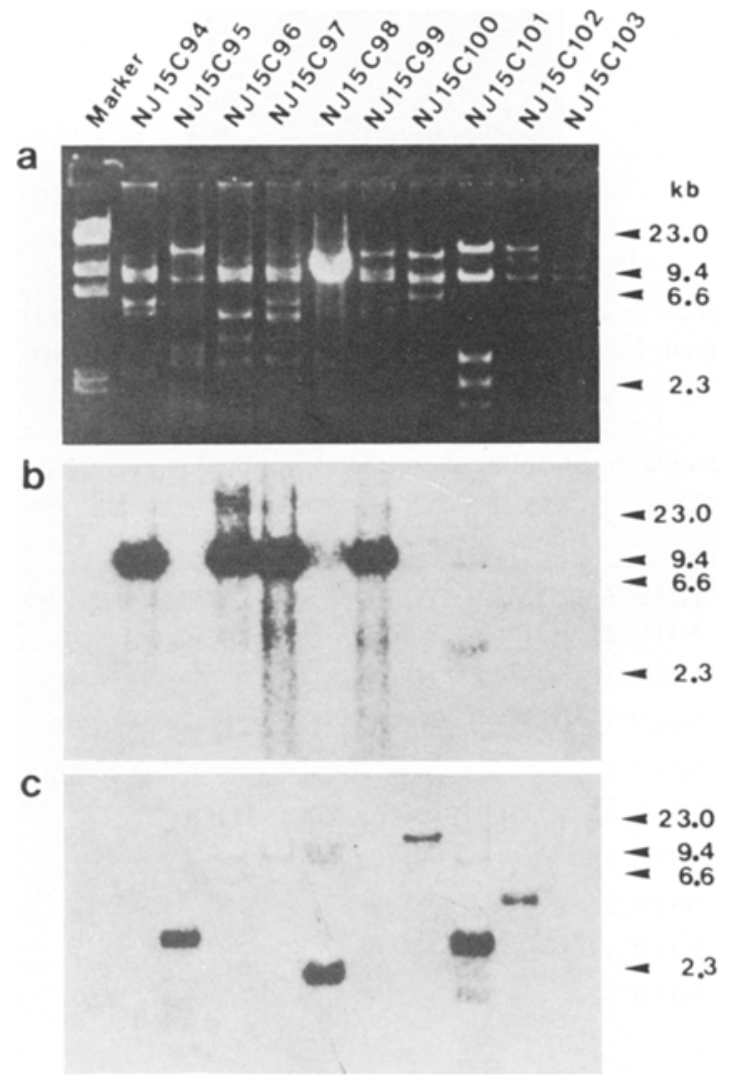

Fig. 2. Ethidium bromide staining of EcoRI digests of cosmid clones (NJ15C94-NJ15C103) after electrophoresis on a $0.8 \%$ agarose gel (a), and Southern blot hybridization of the same digests using two microclone probes, pM15C292d (b) and pM15C293a (c). Four cosmid clones, NJ15C98, NJ15C100, NJ15C102, and $\mathrm{NJ} 15 \mathrm{C} 103$, are independent, while others are overlapping, because NJ15C94, $\mathrm{NJ} 15 \mathrm{C} 96, \mathrm{NJ} 15 \mathrm{C} 97$, and $\mathrm{NJ} 15 \mathrm{C} 99$ have an identical $9.4 \mathrm{~kb}$ fragment and common EcoRI digestion patterns, similarly NJ15C95 and NJ15C101 as well.

\section{Cosmid library screening and regional mapping by FISH}

By the cosmid library screening using the 26 unique or low-repetitive microclones as probes, 66 cosmid clones were isolated. Restriction patterns and Southern blot hybridization revealed that all but 19 cosmids were independent (Fig. 2), Of 


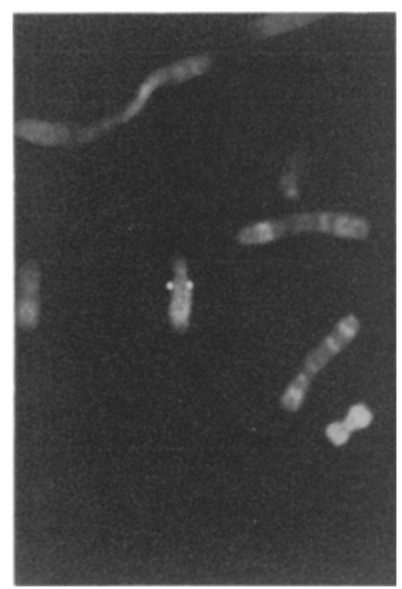

Fig. 3. Fluorescence in situ hybridization using a cosmid clone, NJ15C3, as a probe. FITC signal is observed at 15q12. Photograph was taken with filter B-2A (Nikon).

Table 2. Chromosomal localization of cosmid clones by fluorescence in situ hybridization.

\begin{tabular}{|c|c|}
\hline Mapped regions & Cosmid clones \\
\hline $15 \mathrm{p}$ & $\begin{array}{l}\text { NJ15C6, NJ15C10, NJ15C16, NJ15C17, NJ15C21, NJ15C28, NJ15C30, } \\
\text { NJ15C31, NJ15C32, NJ15C108, NJ15C109 }\end{array}$ \\
\hline $15 \mathrm{cen}$ & NJ15C11, NJ15C13, NJ15C14, NJ15C15, NJ15C24 \\
\hline $15 q 11-q 13$ & NJ15C3, NJ15C22, NJ15C39, NJ15C112, NJ15C115 \\
\hline $15 \mathrm{q} 22$ & $\mathrm{NJ} 15 \mathrm{Cl}$ \\
\hline $15 \mathrm{q} 24$ & NJ15C42, NJ15C113, NJ15C114, NJ15C117 \\
\hline $15 \mathrm{q} 26$ & $\mathrm{NJ} 15 \mathrm{C} 37$ \\
\hline $3 \mathrm{p} 14$ & NJ15C5 \\
\hline $4 \mathrm{p} 16$ & NJ15C4 \\
\hline $\begin{array}{l}1 \mathrm{cen}, 4 \mathrm{cen}, 5 \mathrm{cen} \\
\text { and } 19 \mathrm{cen}\end{array}$ & $\mathrm{NJ} 15 \mathrm{C} 41$ \\
\hline
\end{tabular}

the 47 independent cosmids used as probes for FISH, 16 were assigned to $15 \mathrm{p}$-cen, 5 to q11-q13 (Fig. 3), 6 to other regions of chromosome 15, and 3 to 4p16,3p14, and centromeres 1, 4, 5, and 19, respectively (Table 2). The remaining 17 cosmids gave either no FISH signals or multi-signals on many chromosomes.

\section{DISCUSSION}

A $15 q 11-q 13$ region may contain many copies of instable, repetitive sequences. In order to try to obtain unique clones efficiently, we collected a relatively large 
number (100 pieces) of chromosomal segments dissected from the region. Nevertheless, the proportion $(13.5 \%)$ of unique microclones obtained was smaller than that $(20-50 \%)$ from the microdissection of other chromosomal regions with the same methods, although their mean size was well comparable to that from other regions (Hirota et al., 1992; Seki et al., 1993; Karakawa et al., 1993). There has been only a similar 15q11-q13 specific microlibrary that was constructed by means of microdissection and subsequent PCR (Lüdecke et al., 1990; Buiting et al., 1990), where unique clones took $39 \%$, the cloning efficiency being comparable to that $(39 \%)$ in 22 q12-q13.1 specific microclones, but lower than that $(63-80 \%)$ in their other microclone libraries (Lüdecke et al., 1990). Thus, it is conceivable that the fewer unique clones obtained from 15q11-q13 in the present study are attributable to a particular structure of DNA in this chromosomal region and/or in the paracentromeric regions of acrocentric chromosomes.

Among the cosmid clones screened from a cosmid library, 16 were assigned to $15 \mathrm{p}-\mathrm{cen}, 5$ to $15 \mathrm{q} 11-\mathrm{q} 13,6$ to $15 \mathrm{q} 22-\mathrm{q} 26$, and 3 to other chromosomes. All together, $21(44.7 \%)$ cosmids were mapped to paracentromeric regions of chromosome 15 , the localizations corresponding to the dissected region. The 16 cosmids mapped to $15 \mathrm{p}$-cen also gave FISH signals at the centromeres of other acrocentrics. These findings may have indicated that some of the original microclones shared low-repetitive sequences with other chromosomal regions. In fact, a cosmid clone, NJ15C4, mapped at 4p16 was detected by two microclones, MC16 and MC62, while MC16 detected NJ15C3 that was mapped at 15q12, and MC62 detected both $\mathrm{NJ} 15 \mathrm{Cl}$ and $\mathrm{NJ} 15 \mathrm{C} 5$ which were mapped at $15 \mathrm{q} 22$ and at $3 \mathrm{p} 14$, respectively. Corresponding sequences between chromosomes 15 and 4 were observed by a recent study by Youngman et al. (1992) that the telomeric $60 \mathrm{~kb}$ of $4 \mathrm{p}$ is homologous to a telomeric region on $15 \mathrm{p}$.

Chromosome 15q11-q13 region is causally associated with PWS and AS. In order to know whether our 5 cosmid clones mapped at 15q11-q13 would be located within the AS critical region, FISH were performed on the metaphase chromosomes of an AS patient who deleted only two PWS/AS region markers, D15S10 and GA$B R B 3$ (Saitoh et al., 1992). Since none of the cosmids were deleted in this patient, they are located outside a segment between D15S10 and GABRB3. Further characterization of these cosmids as well as others is in progress.

Acknowledgments This study was supported in part by Grant-in-Aid for Scientific Research on Priority Areas (Genetic Diseases) and on Human Genome Project by the Ministry of Education, Science and Culture of Japan.

\section{REFERENCES}

Buiting K, Neumann M, Lüdecke H-J, Senger G, Claussen U, Antich J, Passarge E, Horsthemke B (1990): Microdissection of the Prader-Willi syndrome chromosome region and identification of potential gene sequences. Genomics 6: 521-527

Buiting K, Greger V, Brownstein BH, Mohr RM, Voiculescu I, Winterpacht A, Zabel B, Hors- 
themke B (1992): A putative gene family in 15q11-13 and 16p11.2: Possible implications for Prader-Willi and Angelman syndrome. Proc NatI Acad Sci USA 89: 5457-5461

Deng H-X, Yoshiura K, Dirks RW, Harada N, Hirota T, Tsukamoto K, Jinno Y, Niikawa N (1992): Chromosome band-specific painting: Chromosome in situ suppression hybridization using PCR products from a microdissected chromosome band as a probe pool. Hum Genet 89: $13-17$

Donlon TA, Lalande M, Wyman A, Bruns C, Latt SA (1986): Isolation of molecular probes associated with the chromosome 15 instability in the Prader-Willi syndrome. Proc Natl Acad Sci USA 83: 4408-4412

Donion TA (1992): Report of the first international workshop on human chromosome 15 mapping. Cytogenet Cell Genet 61: 161-166

Gardner JM, Nakatsu Y, Gondo Y, Lee S, Lyon MF, King RA, Brilliant MH (1992): The mouse pink-eyed dilution gene: Association with human Prader-Willi and Angelman syndromes. Science 257: 1121-1124

Glenn CC, Nicholls RD, Robinson WP, Saitoh S, Niikawa N, Schinzel A, Horsthemke B, Driscoll DJ (1993): Modification of 15q11-q13 DNA methylation imprints in unique Angelman and Prader-Willi patients. Hum Molec Genet in press

Hamabe J, Fukushima Y, Harada N, Abe K, Matsuo N, Nagai T, Yoshioka A, Tonoki H, Tsukino R, Niikawa N (1991a): Molecular study of the Prader-Willi syndrome: Deletion, RFLP, and phenotype analyses of 50 patients. Am J Med Genet 41: 54-63

Hamabe J, Kuroki Y, Imaizumi K, Sugimoto T, Fukushima Y, Yamaguchi A, Izumikawa Y, Niikawa $N(1991 \mathrm{~b})$ : DNA deletion and its parental origin in Angelman syndrome patients. Am J Med Genet 41: 64-68

Hirota T, Tsukamoto T, Deng H-X, Yoshiura K, Ohta T, Tohma T, Kibe T, Harada N, Jinno $Y$, Niikawa $N$ (1992): Microdissection of human chromosomal regions 8q23.3-q24.11 and 2q33-qter: Construction of DNA libraries and isolation of their clones. Genomics 13: 349 354

Jinno Y, Harada N, Yoshiura K, Ohta T, Tohma T, Hirota T, Tsukamoto K, Deng H-X, Oshimura $M$, Niikawa $N$ (1992): A simple and efficient amplification method of DNA with unknown sequences and its application to microdissection/microcloning. J Biochem 112: 75-80

Karakawa K, Takami K, Nakamura T, Jones C, Fujita S, Ohta T, Jinno Y, Niikawa N, Inazawa J, Ariyama T, Mori T, Takai S, Nishisho I (1993): Isolation of region-specific cosmids by hybridization with microdissection clones from human chromosome 10q11.1-q21.1. Genomics 17: $449-455$

Knoll JHM, Sinnett D, Wagstaff J, Glatt K, Wilcox AS, Whiting PM, Wingrove P, Sikela JM, Lalande $M$ (1993): FISH ordering of reference markers and of the gene for the $\alpha 5$ subunit of the $\gamma$-aminobutyric acid receptor (GABRA 5) within the Angelman and Prader-Willi syndrome chromosomal regions. Hum Molec Genet 2: 183-189

Kuwano A, Mutirangura A, Dittrich B, Buiting K, Horsthemke B, Saitoh S, Niikawa N, Ledbetter SA, Chinault C, Ledbetter DH (1993): Molecular dissection of the Prader-Willi/Angelman syndrome region (15q11-13) by YAC cloning and FISH analysis. Hum Molec Genet 1: 417426

Lüdecke H-J, Senger G, Claussen U, Horsthemke B (1989): Cloning defined region of the human genome by microdissection of banded chromosomes and enzymatic amplification. Nature 338: $348-350$

Lüdecke H-J, Senger G, Claussen U, Horsthemke B (1990): Construction and characterization of band-specific DNA libraries. Hum Genet 84: 512-516

Mattei M-G, Souiah N, Mattei JF (1984): Chromosome 15 anomalies and the Prader-Willi syndrome: Cytogenetic analysis. Hum Genet $66: 313-334$

Nicholls RD, Knoll JHM, Butler MG, Karam S, Lalande M (1989): Genetic imprinting suggested 
by maternal heterodisomy in non-deletion Prader-Willi syndrome. Nature 342: 281-285

Ohta T, Tohma T, Soejima H, Fukushima Y, Nagai T, Yoshiura K, Jinno Y, Niikawa N (1993): The origin of cytologically unidentifiable chromosome abnormalities: Six cases ascertained by the targeted chromosome band painting. Hum Genet 92: 1-5

Okamoto E, Miller DA, Erlanger BF, Miller OJ (1981): Polymorphism of 5-methylcytosine-rich DNA in human acrocentric chromosomes. Hum Genet 58: 225-259

Özcelik T, Leff S, Robinson W, Donlon T, Lalande M, Sanjines E, Shinzel A, Francke U (1992): Small nuclear ribonucleoprotein polypeptide N (SNRPN), an expressed gene in the PraderWilli syndrome critical region. Nature Genet 2: 265-269

Saitoh S, Kubota T, Ohta T, Jinno Y, Niikawa N, Sugimoto T, Wagstaff J, Lalande M (1992): Familial Angelman syndrome caused by imprinted submicroscopic deletion encompassing $\mathrm{GABA}_{\mathrm{A}}$ receptor $\beta 3$-subunit gene. Lancet i: $366-367$

Seki N, Yamauchi M, Saito T, Katakura R, Ohta T, Yoshiura K, Jinno Y, Niikawa N, Hori T (1993): Microdissection and microcloning of genomic DNA markers from human chromosomal region 11q23. Genomics 16: 169-172

Wagstaff J, Knoll JHM, Fleming J, Kirkness EF, Martin-Gallardo A, Greenberg F, Graham JM, Menninger J, Ward D, Venter JC, Lalande M (1991): Localization of the gene encoding the $\mathrm{GABA}_{\mathrm{A}}$ receptor $\beta 3$ subunit to the Angelman/Prader-Willi region of human chromosome 15. Am J Hum Genet 49: 330-337

Waters MF, Nicholls RD, Glenn CC, Jong MTC, Surti U, Williams CA, Whidden EM, Driscoll DJ (1992): Expression studies of a gene showing a DNA methylation imprint located in the critical region of the Angelman and Prader-Willi syndromes. Am J Hum Genet 51: A124 only

Youngman S, Bates GP, Williams S, McClatchey AI, Baxendale S, Sedlacek Z, Altherr M, Wasmuth JJ, MacDonald ME, Gusella JF, Sheer D, Lehrach H (1992): The telomeric $60 \mathrm{~kb}$ of chromosome arm $4 p$ is homologous to telomeric regions on $13 p, 15 p, 21 p$, and 22p. Genomics 14: $350-356$ 